\title{
DAMPAK PERUBAHAN IKLIM TERHADAP PERMUKIMAN PESISIR DI KELURAHAN DEMAAN KABUPATEN JEPARA
}

\author{
Climate Change Impact Toward To The Coastal Settlements \\ In Demaan Sub-District, Jepara Regency
}

\section{Sunarti ${ }^{1}$, Nur Khasanah Apriliasari}

Diterima: 7 Oktober 2015

Disetujui: 17 November 2015

\begin{abstract}
Abstrak: Meningkatnya perubahan iklim mempengaruhi kehidupan masyarakat dan sumberdaya hayati, khususnya yang berada di wilayah pesisir. Salah satu kawasan pesisir di Jawa Tengah yaitu Kelurahan Demaan, Kabupaten Jepara terkena secara langsung dampak perubahan iklim. Masyarakat yang bermukim pada kawasan tersebut sering terkena pasang surut air laut dan rob. Hal ini menyebabkan masyarakat melakukan adaptasi terhadap lingkungannya. Tujuan penelitian ini adalah mengidentifikasi dampak perubahan iklim terhadap permukiman di kawasan pesisir Kelurahan Demaan Kabupaten Jepara. Pendekatan penelitian yang digunakan adalah metode campuran konkuren, yaitu dengan menggabungkan data kualitatif dan kuantitatif. Metode kuantitatif digunakan untuk mengetahui karakteristik masyarakat dari hasil kuesioner yang diolah dengan analisis deskriptif, sedangkan metode kualitatif digunakan untuk menjelaskan permasalahan, dan temuan yang terjadi serta dampak perubahan iklim dan adaptasi yang dilakukan masyarakat. Dampak perubahan iklim yang terjadi adalah kenaikan temperature, pasang surut air laut, banjir, rob, air asin, sedimentasi, kekeringan, angin kencang. Bentuk adaptasi yang dilakukan masyarakat antara lain dengan perbaikan lantai, dinding dan atap rumah. Sedangkan bentuk penanganan prasarananya adalah peninggian dimensi jalan, perbaikan drainase, membuat MCK komunal dan pembuangan sampah ke TPS serta depo transfer dekat pasar Apung di Kelurahan Demaan. Rekomendasi pemerintah harus membuat regulasi dan pengawasan untuk pembangunan permukiman di kawasan yang rawan terhadap bencana.
\end{abstract}

\section{Kata kunci: Adaptasi, Permukiman Pesisir, Perubahan Iklim}

\begin{abstract}
Increasing of the climate change influences the community life and natural resources in the coastal areas. Demaan Sub-district, Jepara Regency as the coastal area directly have an impact of climate change such as a tidal flood. This condition makes the community doing adaptation toward to their environment. The research objective is identifying of climate change toward to the settlement in Demaan coastal area. The research approach used mix method of concurrent by combining data of quantitative and qualitative. A quantitative method used to find out the respondents characteristic from the questionnaire result by descriptive statistical analysis. A qualitative method used to explain the problem and study findings of climate change impact and adaptation conducted by the community. The climate change impact in Demaan coastal area which increased in temperature, tide timetable, tidal flood, brine, sedimentation, dryness, and strong wind. The community conducted adaptation by upgrading on floor, wall, and rooftop. Upgrading of infrastructures by rising of road dimension, improving drainage system, developing public sanitation, and improving waste disposal manage by a provision of landfill close to Apung Market. The Government recommendation should develop related regulation and monitoring of the settlement development in the vulnerable areas of disasters.
\end{abstract}

Keyword: adaptation, coastal settlement, climate change

\footnotetext{
${ }^{1}$ Jurusan Perencanaan Wilayah dan Kota, Fakultas Teknik-Universitas Diponegoro
}

Korespondensi:n4rti08@gmail.com 


\section{PENDAHULUAN}

Perubahan Iklim/ climate change merupakan perubahan kondisi fisik atmosfer bumi, seperti suhu dan distribusi curah hujan yang membawa dampak luas terhadap berbagai sektor kehidupan (Kementerian Lingkungan Hidup, 2001). Perubahan kondisi fisik yang dimaksud tidak terjadi hanya dalam waktu sesaat, melainkan dalam kurun waktu yang panjang. Hal ini diperjelas oleh UNFCCC (United Nations Framework Convention on Climate Change) (dalam IPCC glossary working group III, UN-Habitat, 2011) yang menyatakan bahwa perubahan iklim secara langsung ataupun tidak langsung disebabkan oleh aktivitas manusia yang mengubah komposisi atmosfer dan guna lahan, serta adanya perubahan karena sebab alami dalam periode waktu yang lama (Awuor, 2009). Perubahan iklim ini memberikan dampak terhadap kehidupan yang sulit untuk dihindari. Menurut LAPAN (2009), dampak ekstrim dari perubahan iklim adalah terjadinya kenaikan temperatur serta pergeseran musim. Kenaikan temperatur menyebabkan es dan gletser di Kutub Utara dan Selatan mencair, sehingga menyebabkan terjadinya pemuaian massa air laut dan kenaikan permukaan air laut. Hal ini dapat menurunkan produksi tambak perikanan serta mengancam kehidupan masyarakat pesisir pantai (Un Habitat, 2011; Awour, 2009; McGranahan, 2007).

Melihat fenomena dan dampak ekstrim dari perubahan iklim tersebut, tanpa disadari menuntut adanya suatu adaptasi dan mitigasi. Adaptasi dan mitigasi merupakan bentuk penanganan terhadap perubahan iklim yang terjadi. Mitigasi mempunyai makna pengurangan, dalam hal ini mitigasi terhadap perubahan iklim berupa usaha yang dilakukan untuk mengurangi penyebab dari perubahan iklim sehingga laju perubahan dapat melambat. Sedangkan adaptasi lebih menekankan pada penyesuaian diri terhadap perubahan yang ada guna kelangsungan hidup (UN Habitat, 2011). Adaptasi terhadap perubahan iklim merupakan hal yang perlu dilakukan di Indonesia mengingat dampak ekstrim dari perubahan iklim lebih kepada ancaman terhadap wilayah pesisir.

Salah satu wilayah pesisir di Indonesia yang mulai terkena dampak dari perubahan iklim adalah wilayah Pesisir Kabupaten Jepara. Berdasarkan pengamatan mulai tahun 1984 sampai 2002, kenaikan muka air laut dari tiga stasiun permanen di pantai utara Jawa, yaitu Tanjung Priuk, Semarang dan Jepara menunjukkan adanya kenaikan sebesar $8 \mathrm{~mm} /$ tahun (Sutisna S., dkk: 2002). Jepara mempunyai wilayah pesisir yang luas dan garis pantai yang panjang karena berbatasan langsung dengan Laut Jawa, diantaranya yaitu Kawasan Pesisir Demaan.

Kondisi fisik lingkungan merupakan faktor penting dalam proses bermukim maupun produk yang berupa permukiman (Bockstael, 1996 dalam Marwasta, 2007). Salah satu faktor yang perlu diperhatikan bagi permukiman pada daerah pesisir adalah kerawanan terhadap bencana alam, terutama yang disebabkan oleh aktivitas laut, misalnya rob dan tsunami (Marwasta, 2007). Adanya bencana merupakan salah satu faktor penyebab kekumuhan kawasan di lingkungan pesisir.

Bencana perubahan iklim perlu diatasi dan diminimalisir sehingga dampak negatif dari bencana dapat berkurang. Upaya dalam menghadapi bencana ini didasarkan pada beberapa pendekatan yang kemudian dijabarkan dalam berbagai strategi. Dengan melihat karakteristik dari bencana perubahan iklim yang terjadi, maka pendekatan yang dilakukan berorientasi pada mengatasi sumber bencananya, maupun meminimalisasi dampak bencana yang ditimbulkan. Beberapa pendekatan yang dapat dilakukan dalam menghadapi perubahan iklim tersebut yaitu (Diposaptono, 2009):

a. Pendekatan Mitigasi

Pendekatan mitigasi merupakan upaya-upaya yang dilakukan untuk mengurangi

bencana dari sumbernya. 


\section{b. Pendekatan Adaptasi}

Pendekatan adaptasi merupakan upaya untuk mengatasi perubahan iklim baik sifatnya reaktif maupun antisipatif. Pendekatan ini sifatnya mengaktisipasi dampak akibat terjadinya perubahan iklim, yaitu dengan melakukan proses penyesuaian diri dengan kondisi perubahan iklim yang ada.

Kedua pendekatan diatas secara umum memiliki perbedaan, pendekatan mitigasi lebih menitik beratkan pada upaya-upaya untuk mengurangi terjadinya perubahan iklim melalui tindakan-tindakan preventif seperti meminimalisasi limbah industri, menggerakkan kegiatan-kegiatan yang ramah lingkungan (Awuor, 2009). Sedangkan pendekatan adaptasi lebih menekankan pada penyesuaian-penyesuaian terhadap perubahan yang terjadi karena dampak perubahan iklim. Pendekatan ini dilakukan untuk mempertahankan eksistensi dan kehidupan wilayah pesisir, khususnya permukiman yang ada didalamnya (McGranahan, 2007; Awuor, 2009).

Kawasan Pesisir Kelurahan Demaan Kecamatan Jepara dimanfaatkan oleh banyak orang untuk bermukim. Banyaknya masyarakat yang bermukim di kawasan pesisir dengan luas wilayah yang tidak terlalu luas membuat tingkat kepadatan di kawasan pesisir ini cukup tinggi dan cenderung kumuh. Kondisi lingkungan permukiman yang kumuh, ditunjang dengan adanya permasalahan kenaikan muka air laut sangat mempengaruhi aktivitas dan pola masyarakat dalam bermukim. Meskipun demikian, masih banyak warga yang tetap bertahan bermukim di wilayah ini dengan kondisi permukiman yang kurang layak huni. Kondisi permukiman yang demikian tanpa disadari membuat masyarakat cenderung beradaptasi, dengan menyesuaikan diri agar dapat tetap bertahan hidup.

Kondisi kawasan pesisir Kelurahan Demaan yang ditinggali oleh banyak penduduk untuk bermukim pada kondisi wilayah yang rentan akan kenaikan muka air laut akibat perubahan iklim sehingga menuntut masyarakat untuk beradaptasi guna mempertahankan hidupnya perlu dikaji lebih mendalam.

Kajian ini dilakukan guna mengetahui sejauh mana respon masyarakat dalam mempertahankan kehidupannya bermukim di kawasan pesisir tersebut. Respon yang dimaksud adalah upaya penyesuaian yang dilakukan masyarakat agar dapat bertahan dan tetap bermukim.

Berdasarkan permasalahan di atas maka tujuan dalam penelitian ini adalah mengkaji dampak perubahan iklim terhadap permukiman pesisir dan bentuk adaptasi masyarakat dalam bermukim di Kelurahan Demaan Kabupaten Jepara.

\section{METODE PENELITIAN}

Strategi penelitian menggunakan metoda campuran konkuren (concurrent mixed methods) yaitu mempertemukan atau menyatukan data kuantitatif dan data kualitatif untuk memperoleh analisis komprehensif atas masalah penelitian. Peneliti mengumpulkan dua jenis data tersebut pada satu waktu, kemudian menggabungkannya menjadi satu informasi dalam interpretasi hasil keseluruhan (Creswell, 2010). Metode analisis deskriptif kualitatif dan statistik deskriptif untuk menjelaskan adaptasi masyarakat secara lengkap terkait dengan bentuk adaptasi masyarakat dalam bermukim di kawasan pesisir sesuai dengan permasalahan yang ada di lokasi penelitian.

Teknik pengumpulan data yaitu pengumpulan data primer dan sekunder. Data primer dilakukan dengan wawancara terhadap tokoh masyarakat dan instansi kelurahan untuk mengetahui dampak perubahan iklim yang terjadi dan bentuk adaptasi masyarakat dalam bermukim terhadap bahaya perubahan iklim tersebut. Selain itu data primer didapat dengan menyebaran kuesioner terhadap masyarakat dan observasi lapangan terhadap bentuk adaptasi bangunan rumah terhadap bahaya perubahan iklim. 
Sedangkan teknik analisis menggunakan analisis deskriptif kualitatif dan statistik deskriptif. Teknik analisis deskriptif kualitatif yaitu teknik analisis yang menstransformasikan data mentah kedalam bentuk data yang mudah dimengerti dan diintepretasikan, serta menyusun dan menyajikan data menjadi suatu informasi yang jelas (Sugiyono, 2008). Sedangkan statistik deskriptif menurut Sugiyono; 2008 adalah statistik yang berfungsi untuk mendeskripsikan atau memberi gambaran terhadap obyek yang diteliti melalui data sampel atau populasi sebagaimana adanya, tanpa melakukan analisis dan membuat kesimpulan yang berlaku untuk umum.

\section{HASIL PEMBAHASAN}

Kelurahan Demaan memiliki karakteristik sebagai wilayah perkotaan yang terletak di pesisir. Kawasan ini memiliki karakteristik yang dapat ditinjau dari kondisi fisik hunian dan infrastrukturnya. Apabila ditinjau dari kondisi fisik huniannya, kawasan pesisir khusunya di RW IV dan V merupakan kawasan permukiman padat dengan jarak antar bangunan berkisar 0,5-1 meter. Permukiman ini hanya berjarak $<100$ meter dari laut yang berarti masyarakat tinggal di kawasan lindung yang tidak seharusnya digunakan sebagai kawasan permukiman. Bangunan pada kawasan ini sebagian besar berupa bangunan non permanen satu lantai.

Kondisi permukiman di Kelurahan Demaan memiliki fasilitas umum yang lengkap antara lain sarana perdagangan dan jasa, peribadatan, perkantoran, pendidikan, serta olahraga. Berbagai fasilitas umum ini berada pada jalan-jalan utama kawasan perkotaan yang lokasinya jauh dari laut. Jaringan jalan di Kelurahan Demaan membentuk sistem grid, yang terdiri dari jalan kabupaten serta jalan lingkungan. Kondisi jalan cukup baik karena sudah diaspal dan dipaving, hanya pada beberapa jalan lingkungan di daerah pantai yang mengalami kerusakan akibat rob. Untuk sanitasi sebagian besar masyarakat membuang limbahnya ke sungai. Bahkan, warga yang tinggal di pesisir pantai membuat jamban di tepi laut (jamban helikopter) karena masih banyak warga yang belum memlliki MCK pribadi. Tidak berbeda jauh dengan sanitasi, drainase di kelurahan ini dengan kondisi tidak baik. Drainase banyak yang tersumbat oleh sampah yang terbawa akibat pasang air laut maupun air hujan. Hal ini menyebabkan disekitar saluran terjadi genangan akibat drainase tersumbat oleh sampah, sehingga menyebabkan aktivitas warga dapat terganggu. Genangan air yang cukup tinggi $(20-30 \mathrm{~cm})$ terutama terjadi pada permukiman di daerah pantai. Untuk jaringan air bersih sebagian besar telah terpenuhi oleh PDAM dan hanya beberapa yang menggunakan sumur. Sedangkan untuk fasilitas persampahan, telah terdapat TPS, namun tetap masih ada warga yang membuang sampah ke laut atau selokan. Kebiasaan warga membuang sampah di laut ini memang sengaja dilakukan agar daratannya tidak cepat habis terkena ombak.

\section{Analisis Karakteristik Masyarakat Kelurahan Demaan}

Berdasarkan data Kecamatan Jepara dalam angka tahun 2010, jumlah penduduk di Kelurahan Demaan sebanyak 5.121 jiwa, yang didominasi penduduk usia anak-anak dan remaja. Jumlah penduduk tersebut tersebar di 7 RW. Kepadatan penduduk tertingggi berada di RW V. Penduduk di Kelurahan Demaan ini sebagian besar (61\%) adalah penduduk asli, sedangkan sisanya berasal dari kelurahan lain, kabupaten sekitar, dan bahkan berasal dari luar Pulau Jawa. Perbedaan asal daerah penduduk ini menyebabkan lama tinggal masyarakat yang bervariasi, ada yang tinggal selama $<10$ tahun, 10-25 tahun, $>25$ tahun. Status kepemilikan bangunan ada yang sudah hak milik (HM), da nada yang sewa, hak guna bangunan (HGM), dan ada yang hanya sekedar menumpang pada 
bangunan milik orang lain. Namun, sebagian besar (81\%) bangunannya berstatus hak milik. Secara umum, tingkat pendidikan masyarakat di Kelurahan Demaan bervariasi, ada yang berpendidikan terakhir perguruan tinggi, SMA, SMP, SD, dan ada yang tidak sekolah. Organisasi non pemerintah yaitu yang berupa kelompok masyarakat, seperti BKM dibentuk sebagai sarana untuk mengatasi permasalahan fisik lingkungan permukiman masyarakat.

Masyarakat Kelurahan Demaan yang tinggal di kawasan pesisir (RW IV dan V), sebagian besar $(27 \%)$ bermata pencaharian sebagai nelayan. Mata pencaharian lainnya adalah wirausaha/ swasta, PNS, pedagang, dan buruh nelayan. Tingkat pendapatan dan pengeluaran masyarakat sebanyak 30\% berpendapatan di bawah UMR (<Rp 800.000,-), terutama warga yang tinggal di kawasan pesisir (RW IV dan V). Sedangkan untuk pengeluarannya, berkisar antara Rp 1.000.000,00 - Rp 1.500.000,00.

\section{Analisis Fenomena Perubahan Iklim di Kelurahan Demaan}

Potensi dampak perubahan iklim antara lain kenaikan permukaan laut yang dapat mempengaruhi suatu wilayah yang meliputi peningkatan terjadinya badai, menyebabkan terjadinya banjir, erosi pantai laut; intrusi air asin ke muara dan akuifer air tawar, perubahan pola sedimentasi. Suhu udara rata-rata tinggi, kelembaban, faktor social ekonomi dan permukiman yang tidak terencana dengan struktur yang tidak layak menjadi pemicu meningkatnya perubahan iklim (McGranahan, 2007; Awour, 2009).

Kelurahan Demaan di kawasan pesisir seperti yang diungkapkan Awour, lokasi tersebut terkena perubahan iklim sehingga kondisinya rentan terjadi rob, adanya angin kencang, dan air menjadi asin, serta abrasi (berkurangnya daratan karena ombak laut). Selain itu, rentan terjadi kekeringan pada musim kemarau yang terlalu panas dan menyebabkan sumber air bersih penduduk kering serta saluran drainase mengalami sedimentasi akibat tanah/lumpur yang mengering.

Daerah yang tergolong rawan rob adalah daerah yang diukur dari 200 meter dari laut (wilayah RW IV dan V), sedangkan daerah rawan banjir berada pada daerah Sungai Kanal (wilayah RW I dan II). Selain kedua bahaya tersebut, wilayah Kelurahan Demaan juga rawan terjadi genangan air hujan yang cukup tinggi $( \pm 30 \mathrm{~cm})$ dengan durasi waktu genangan selama 3 jam. Adanya genangan ini disebabkan naiknya permukaan air laut yang masuk ke daratan melalui sungai-sungai sehingga menggenangi wilayah daratan yang lebih rendah. Selain itu, genangan tersebut juga terjadi karena adanya perubahan lahan, dimana semakin banyaknya lahan terbangun dibandingkan lahan terbuka hijau. Untuk lebih mengetahui daerah rawan bencana rob dan banjir ditunjukkan pada Gambar 1 di bawah ini.

\section{Analisis Dampak Perubahan Iklim Terhadap Fisik Lingkungan Permukiman}

Adanya fenomena perubahan iklim membawa dampak pada peningkatan curah hujan yang cukup tinggi sehingga akan menyebabkan semakin meningkat pula bahaya genangan air, pasang surut air laut, perubahan suhu dan kadar keasaman air laut, angin yang semakin kencang, serta peningkatan intensitas gelombang laut. Berdasarkan dari hasil wawancara terhadap masyarakat, bahwa apabila air laut pasang, maka air tersebut akan masuk melalui sungai maupun drainase, dan akan menggenangi daerah dataran rendah. Sedangkan apabila air pasang bersamaan dengan turunnya hujan, maka akan terjadi banjir karena air hujan tidak dapat masuk ke laut (karena muka air laut yang tinggi). Dengan adanya fenomena tersebut, masyarakat setempat melakukan upaya penutupan lahan dengan menggunakan tanah, pasir maupun sampah sehingga dapat mereka jadikan lokasi untuk mendirikan rumah. Padahal lokasi ini masih termasuk ke dalam sempadan pantai yang seharusnya berfungsi sebagai kawasan lindung. Genangan ini terjadi di hampir seluruh wilayah Kelurahan Demaan, antara lain wilayah yang terkena genangan cukup tinggi (30 
$\mathrm{cm}$ ) adalah di RW IV dan V. Pada RW VI masih tergolong aman dan jarang terjadi genangan, kecuali pada saat hujan karena di wilayah tersebut sudah terdapat saluran drainase. Adanya genangan dipengaruhi oleh kondisi topografi, sehingga daerah pantai lebih sering terjadi genangan dibandingkan pada daerah yang mempunyai topografi yang lebih tinggi. Pada daerah perbukitan relatif aman dan tidak terjadi genangan karena masih terdapat vegetasi yang mampu meresap air ke dalam tanah. Selain itu adanya genangan tersebut, dampak lain yang timbul dari adanya perubahan iklim adalah kerusakan terumbu karang akibat kenaikan muka air laut, terkikisnya daratan hasil urugan warga akibat air pasang dan adanya sedimentasi pantai, serta adanya tanah longsor di daerah perbukitan karena hujan deras dan kondisi tanah yang labil.

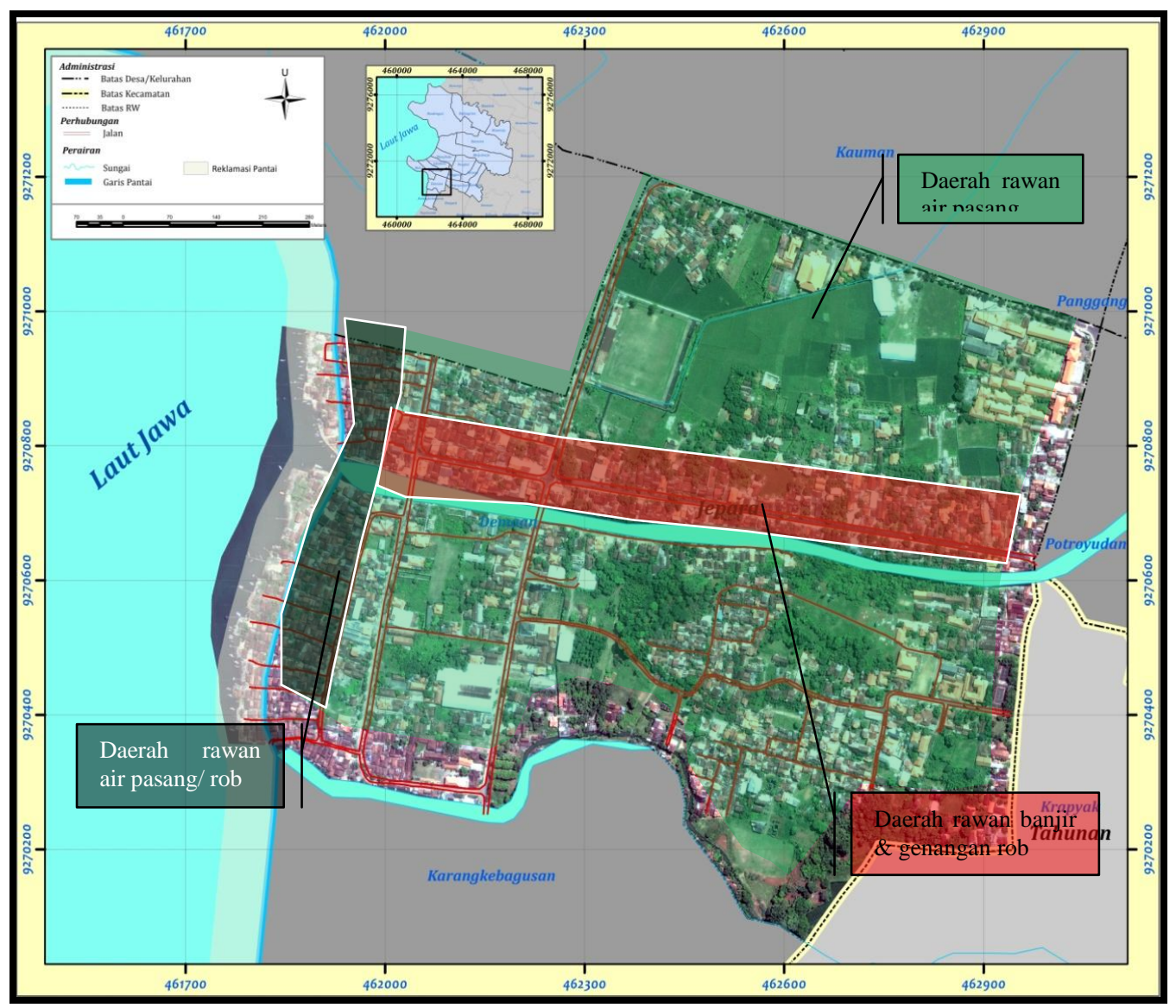

Sumber: Pengolahan Peta Rawan Bencana SPPIP Kab.Jepara 2011, Peta Rawan Bencana RTRW Kab.Jepara $2011-2031$

Gambar 1. Peta Rawan Bencana di Kelurahan Demaan Kabupaten Jepara

Adanya perubahan iklim juga membawa dampak terhadap hunian warga di wilayah sempadan pantai yang memiliki kepadatan bangunan tinggi, menyebabkan kurangnya daya serap air ke dalam tanah. Bangunan di wilayah ini strukturnya masih terbuat dari bambu, hanya sebagian saja yang sudah terbuat dari tembok. Dinding ini dibuat untuk menahan terjangan angin maupun ombak. Beberapa hunian yang mengalami banyak kerusakan yaitu pada bagian atap dan dinding. Wilayah sempadan pantai yang seharusnya bebas dari 
bangunan, harus terbebas dari bangunan. Bangunan yang terletak di sempadan pantai dengan jarak kurang dari 10 meter merupakan bangunan illegal dan harus dikendalikan.

Dampak perubahan iklim selain berdampak pada kondisi fisik bangunan rumah juga berdampak pada kerusakan infrastruktur lingkungan. Prasarana yang mengalami kerusakan antara lain jalan, drainase, sanitasi, dan air limbah. Lokasi yang mengalami kerusakan letaknya sekitar 200 meter dari bibir pantai. Jaringan jalan yang mengalami kerusakan akibat tergenang air laut saat rob, adalah jalan lingkungan yang terdapat pada wilayah sempadan pantai, seperti jaringan jalan di RW IV dan V. Pada wilayah tersebut telah mendapat bantuan perbaikan jalan dari PNPM dan P2KP (Program Peningkatan Kualitas Permukiman) sehingga jalan telah kembali berada dalam kondisi baik dan telah muncul jaringan jalan yang baru. Selain jaringan jalan, prasarana lain yang perlu diperhatikan adalah saluran drainase yang mengalami penyumbatan dan sedimentasi akibat air laut dan limbah. Hal ini menyebabkan drainase tercemar air laut dan berbau. Oleh karena itu, beberapa warga telah meninggikan drainasenya, seperti di RW III, IV, dan V. Untuk sanitasi dan pembuangan limbah sendiri, masih dilakukan masyarakat di laut sehingga dapat mencemari air laut. Oleh karena itu, pada bulan Mei 2012 dikembangkan sanitasi lingkungan berbasis masyarakat (SLBM) yang berupa MCK plus, yaitu kamar mandi komunal dengan sanitasi yang lengkap. Dengan adanya MCK komunal ini diharapkan dapat memenuhi kebutuhan warga akan sistem sanitasi yang bersih. Tidak berbeda jauh dengan sanitasi, sistem persampahan di Kelurahan Demaan juga masih memanfaatkan laut. Pembuangan sampah dilakukan di laut dengan maksud untuk menambah luasan daratan dan reklamasi pantai sehingga diharapkan dapat menghadang arus ombak laut agar tidak mencapai rumah mereka. Selain dilakukan pada wilayah sempadan pantai, kegiatan ini juga dilakukan warga di sempadan sungai sehingga menyebabkan genangan yang memasuki lingkungan permukiman warga, terutama pada saat terjadi hujan. Berbeda dengan prasarana di wilayah Kelurahan Demaan yang rentan terkena bencana, untuk sarana umumnya masih berada pada kondisi aman karena lokasinya yang strategis dan tidak terlalu dekat dengan pantai. Gambar 2 dibawah ini dapat dilihat klasifikasi jenis kerentananan di Kelurahan Demaan akibat adanya perubahan iklim.

\section{Analisis Bentuk Adaptasi Masyarakat dalam Bermukim}

Bentuk adaptasi yang dilakukan masyarakat dalam menghadapi berbagai bencana disesuaikan dengan kondisi sosial ekonomi serta karakteristik masyarakat sebagai masyarakat pesisir atau masyarakat perkotaan. Bentuk adaptasi masyarakat yang tinggal di sekitar Pasar Apung dan di sempadan pantai membuat tonggak pemecah gelombang. Selain itu, masyarakat juga meninggikan daratan dengan menancapkan jeruji bambu yang kemudian diisi dengan sampah. Namun, cara ini menimbulkan pencemaran sehingga perlu diganti dengan cara lain yang lebih aman, yaitu merelokasi permukiman di sempadan pantai kemudian digunakan sebagai ruang terbuka hijau.

Menurut UN Habitat, 2011 salah satu cara untuk adaptasi terhadap dampak perubahan iklim di pantai adalah pembangunan infrastruktur dengan memperbaiki dan memelihara dinding laut.

Hal ini dapat untuk menghalangi terjangan ombak dari laut. Awour, 2009 menyatakan bahwa untuk mengurangi kerentanan terhadap perubahan iklim terutama dengan keterbatasan lahan untuk permukiman yaitu mendorong pemerintah kota untuk membangun permukiman di pinggiran kota yang jauh dari pantai. Selain itu membangun bangunan yang kokoh dengan ventilasi yang dapat untuk sirkulasi udara alami sehingga dapat mengurangi kelembaban yang tinggi dalam ruangan. 


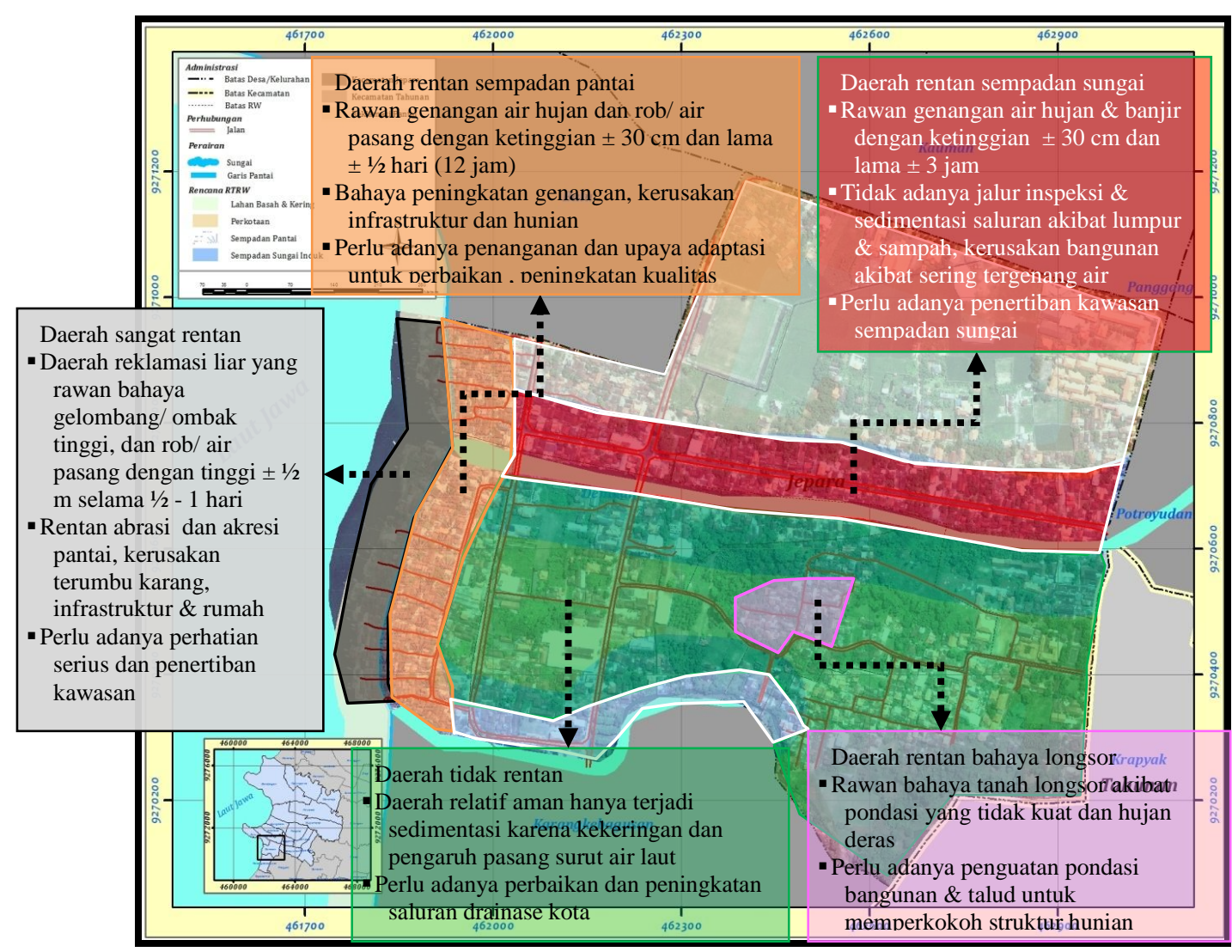

Sumber: Hasil Analisis, 2012

\section{Gambar 2. Klasifikasi Tingkat Kerentanan Kawasan Terhadap Bahaya dan Dampak Perubahan Iklim di Kelurahan Demaan Kabupaten Jepara}

Bentuk adaptasi masyarakat Kelurahan Demaan terhadap hunian mereka seperti dengan meninggikan lantai bangunan atau menambah jumlah lantai menjadi bertingkat tanpa menambah luasan rumah. Selain itu, beberapa warga juga melakukan perubahan struktur bangunan menjadi bangunan permanen. Bangunan yang berbatasan langsung dengan sungai, terutama pada sisi kanan sungai, memiliki ketinggian lantai dasar bangunan yang lebih tinggi untuk menghindari adanya genangan air yang memasuki rumah mereka. Berbagai bentuk adaptasi yang dilakukan masyarakat sebagian besar menggunakan dana pribadi dan hanya beberapa orang yang menggunakan dana bantuan dari pemerintah (PNPM).

Bentuk adaptasi akibat perubahan iklim terhadap kerusakan infrastruktur di RW IV dan $\mathrm{V}$ yaitu dengan perbaikan jalan. Bentuk perbaikan jalan yang dilakukan secara terus menerus yaitu dengan cara dipaving/dibeton dan dimensinya dibuat lebih tinggi sehingga dapat mengurangi kemungkinan terjadinya genangan air.

Jaringan drainase di RW I dilakukan perbaikan pada saluran yang berada di sempadan sungai yang mengalami sedimentasi. Hal ini sesuai dengan pernyataan UN Habitat, 2011 bahwa pemeliharaan dan peningkatan system drainase sangat penting untuk mengantisipasi dampak perubahan iklim di kawasan pesisir.

Drainase di sempadan sungai ini seharusnya tersambung dengan drainase primer sehingga dapat mengalir dengan baik. Selain itu, drainase juga perlu disesuaikan dengan 
jaringan jalan agar masyarakat tidak menggunakan drainase tersebut sebagai tempat untuk membuang sampah maupun limbah.

Untuk sistem persampahan, telah disediakan TPS pada semua RW dan depo transfer di RW IV yang terdapat di Pasar Apung. Dengan adanya TPS ini diharapkan dapat memenuhi kebutuhan warga dalam hal pembuangan sampah sehingga tidak ada lagi warga yang membuang sampahnya sembarangan.

Selain jalan, drainase, dan sistem persampahan, adaptasi juga dilakukan masyarakat terhadap sistem sanitasi mereka dengan membangun MCK komunal sehingga masyarakat tidak perlu lagi menggunakan jamban di atas laut (jamban helikopter).

Kebutuhan air bersih masih terlayani dengan baik dari PDAM dengan adanya jaringan yang menuju ke Kelurahan Demaan.

\section{KESIMPULAN DAN REKOMENDASI}

Hasil analisis mengenai identifikasi dampak perubahan iklim di lingkungan permukiman Kelurahan Demaan Jepara dapat disimpulkan bahwa peningkatan curah hujan yang cukup tinggi menyebabkan meningkatnya bahaya genangan air, pasang surut air laut, perubahan suhu dan kadar keasaman air laut, angin yang semakin kencang, dan peningkatan intensitas gelombang laut. Apabila terjadi air laut pasang, maka air laut masuk ke sungai dan drainase sehingga air akan menggenangi kawasan permukiman. Sedangkan apabila air pasang bersamaan dengan turunnya hujan, maka akan terjadi banjir karena air hujan tidak dapat masuk ke laut (karena muka air laut yang tinggi) dan apabila musim kemarau maka berpotensi terjadi kekeringan. Perubahan iklim membawa kerusakan pada hunian masyarakat maupun infrastruktur di dalamnya, seperti atap dan dinding yang rusak karena terkena angin yang kencang dan air pasang. Upaya adaptasi yang dilakukan masyarakat diantaranya adalah perbaikan jalan, drainase, sanitasi, dan renovasi rumah. Rekomendasi untuk pemerintah daerah Kabupaten Jepara adalah pembangunan permukiman di daerah sempadan pantai atau sungai harus dihentikan, karena sangat membahayakan masyarakat. Pembuatan TPS dan depo transfer untuk pembuangan sampah karena untuk mengantisipasi kebiasaan masyarakat membuang sampah di tepi pantai karena dapat merusak lingkungan, memicu abrasi, dan dapat menyebabkan terjadinya sedimentasi. Selain itu relokasi dan menata permukiman yang berada di daerah pesisir, terutama bagi permukiman illegal serta penambahan ruang terbuka hijau pada kawasan pesisir seperti penanaman bakau untuk mencegah air pasang ataupun gelombang. Selain itu menyusun regulasi tentang pelarangan pembangunan rumah di sempadan pantai dan pemberian sanksi terhadap pihak yang membangun pada kawasan pesisir. Pengawasan dan pengendalian pembangunan permukiman di kawasan pesisir perlu diperketat dan perlu ditetapkan garis sempadan sehingga batas pembangunan permukiman yang diperbolehkan dapat lebih jelas.

\section{DAFTAR PUSTAKA}

Awuor, Cynthia Brenda, Victor Ayo Orindi And Andrew Ochieng Adwera. 2009. Climate change and coastal cities: the case of Mombasa, Kenya. Environment and Urbanization 2008 20: 231

Creswell, John W. 2010. Research Design: Pendekatan Kualitatif, Kuantitatif, dan Mixed. Yogyakarta: Pustaka Pelajar

Diposantono, Subandono, dkk. 2009. Menyiasati Perubahan Iklim di Wilayah Pesisir dan Pulau-pulau Kecil. Bogor: Buku Ilmiah Populer.

IPCC, 2011, Pemanasan Global, http://id.wikipedia.org/wiki/Pemanasan global, 20 November 2011. 
IPCC. glossary working group III.

LAPAN, 2009, Adaptasi dan Mitigasi, http://iklim.dirgantaralapan.or.id/index.php?option=com content\&view=article\&id=61\&ltemid=41, 12 Desember 2011.

Laporan Pemetaan Swadaya Kelurahan Demaan Tahun 2010.

Marwasta, Djaka, dan Kuswaji Dwi Piyono. 2007. Analisis Karakteristik Permukiman Desa-Desa Pesisir di Kabupaten Kulonprogo. Jurnal Forum Geografi, Vol. 21, No. 1, Juli 2007: 57 - 68.

McGranahan, Gordon; Deborah Balk and Bridget Anderson. 2007. The rising tide: assessing the risks of climate change and human settlements in low elevation coastal zones. Environment and Urbanization 2007 19: 17

United Nations Human Settlements Programme [UN-Habitat]. 2011. Cities And Climate Change : Global Report On Human Settlements,2011. First published in 2011 by Earthscan London - Washington, DC

United Nation Development Programme Indonesia. 2007. Sisi Lain Perubahan Iklim: Mengapa Indonesia Harus Melakukan Beradaptasi untuk Melindungi Rakyat Miskinnya. Jakarta: UNDP Indonesia Country Office.

United Nations Framework Convention on Climate Change, 2007, Climate Change 2007, www.google.com, 2 November 2011.

Sutisna S., dkk. 2002. Mengelola Resiko Bencana di Negara Maritim Indonesia. Bandung: ITB.

Sugiyono. 2008. Metode Penelitian Kuantitatif, Kualitatif dan R \& D. Bandung: Alfabeta. 